Article

\title{
Discovery of a Potent Anti-Yeast Triterpenoid Saponin, Clematoside-S from Urena lobata $\mathrm{L}$.
}

\author{
Xiao-Ling Gao ${ }^{1, \dagger}$, Ying Liao ${ }^{2, \dagger}$, Jie Wang ${ }^{3, \dagger}$, Xiao-Yan Liu ${ }^{3, \dagger}$, Kai Zhong ${ }^{3}$, Yi-Na Huang ${ }^{4}$, \\ Hong Gao ${ }^{3}$, Bo Gao ${ }^{4, *}$ and Zheng-Jun $\mathrm{Xu}^{1, *}$
}

1 Rice Research Institute, Sichuan Agricultural University, Wenjiang 611130, China;

E-Mail: gaox10908@hotmail.com

2 College of Life Science, Sichuan Normal University, Chengdu 610101, China;

E-Mail: ying_liao@msn.com

3 College of Light Industry, Textile and Food Engineering, Sichuan University, Chengdu 610065, China; E-Mails: wjie0207@163.com (J.W.); 1xy19831231@126.com (X.-Y.L.); eric211@163.com (K.Z.); gao523@hotmail.com (H.G.)

4 West China School of Public Health, Sichuan University, Chengdu 610041, China; E-Mail: dir0932@sina.com

$\dagger$ These authors contribute equally to this work.

* Authors to whom correspondence should be addressed;

E-Mails: gao523@oulook.com (B.G.); mywildrice@aliyun.com (Z.-J.X.);

Tel.: +86-28-8272-6875 (Z.-J.X.); Fax: +86-28-8272-2661 (Z.-J.X.).

Academic Editor: Marcello Iriti

Received: 16 December 2014 / Accepted: 16 February 2015 / Published: 2 March 2015

Abstract: Urena lobata has been used as a traditional medicinal plant in India and China. In this study, we investigated the antimicrobial activity and isolated the active compound from the leaves of $U$. lobata. The $80 \%$ ethanol extract from $U$. lobata leaves showed an effective anti-yeast activity against Saccharomyces cerevisiae (S. cerevisiae) strains. Using a combination of chromatographic methods, (-)-trachelogenin (1) and clematoside-S (2) were isolated from this plant for the first time, and their chemical structure was identified by mass spectrometry (MS) and extensive nuclear magnetic resonance (NMR) data analysis. In addition, $\mathbf{1}$ was found to be inactive against all of the test microorganisms in the antimicrobial assay, whereas $\mathbf{2}$ exhibits a specific anti-yeast activity against $S$. cerevisiae strains with diameter of inhibition zones in the range from 11 to $20 \mathrm{~mm}$. Furthermore, the MIC (minimum inhibitory concentration) and MBC (minimum bactericidal concentration) 
values of 2 against $S$. cerevisiae strains were detected to be in the ranges of 0.61 to $9.8 \mu \mathrm{g} / \mathrm{mL}$ and 2.42 to $9.8 \mu \mathrm{g} / \mathrm{mL}$, respectively. This is the first report of 2 with a specific anti-yeast activity. The above result suggests the potential application of $U$. lobata to be used as a natural anti-yeast agent in food preservation.

Keywords: Urena lobata; triterpene saponin; clematoside-S; anti-yeast activity

\section{Introduction}

Food spoilage by the food-related yeast causes the deterioration of a wide range of foodstuffs such as wines, milk, fruit and vegetable juices, soft drink or meat. Spoilage yeasts not only significantly influence the cost and availability of foods and beverages, but also lead to economic losses in food industry [1-3]. Notably, Saccharomyces cerevisiae is listed on one of the most significant spoilage yeasts for fruit juices and soft drinks [4]. Although chemical preservatives can exclude yeast spoilage, there is a strong consumer demand to avoid or diminish the use of artificial preservatives. Therefore, much effort has been expended in the search for effective natural compounds from herbs and spices in order to control food spoilage caused by yeast and replace existing synthetic antibiotics in foodstuffs $[5,6]$.

Urena lobata L., indigenous in China, is a number of the Malvaceae family. The plant, commonly known as Ye-Mian-Hua in China, is a popular folk medicine as diuretic, febrifuge, and also as a remedy for dysentery, cough, dropsy and rheumatism to exhibit a variety of biological activities, including antioxidant, anti-inflammatory, anti-proliferative, and antibacterial activities [7-9]. Recently, it has been reported that the methanolic extract from $U$. lobata leaves showed antibacterial activity against Micrococcus roseus and Mycobacterium smegmatis [10]. Some phytochemical compounds such as flavonoids, triglycerides and lignans have been isolated from this plant [11-13]. In the course of our ongoing program on identifying antimicrobial principles from natural materials, we found that the aqueous ethanolic extract from the leaves of $U$. lobata showed significant anti-yeast activity using S. cerevisiae as an indicator. In the present study, we have attempted to isolate the anti-yeast substance(s) from the leaves of $U$. lobata. On bioassay guided fractionation of aqueous ethanolic extract, further work led to the isolation of (-)-trachelogenin (1) and clematoside-S (2) (Figure 1). Herein, we describe the isolation and structural elucidation of compounds $\mathbf{1 - 2}$, together with evaluating their antibacterial and antifungal activities.

\section{Results and Discussion}

\subsection{Isolation of Compounds 1-2 from the Leaves of Urena lobata}

Scheme 1 shows the extract and isolation scheme of compounds 1-2 from the leaves of U. lobata. Powdered leaves of $U$. lobata were extracted with $80 \%$ ethanol and further fractionation was performed with a guidance of inhibitory zone diameter against $S$. cerevisiae (ATCC 204508). At a concentration of $10 \mathrm{mg} / \mathrm{mL}$, the crude extract exhibited $15 \mathrm{~mm}$ of inhibitory zone diameter against $S$. cerevisiae. The extract was subjected to MCI gel column chromatography to give four fractions with a step 
gradient elution of water-methanol. The active fraction 4 (16 $\mathrm{mm}$ of inhibitory zone diameter against S. cerevisiae at a concentration of $10 \mathrm{mg} / \mathrm{mL}$ ) eluted with $100 \%$ methanol, was further purified by preparative HPLC to afford compounds $\mathbf{1}$ and $\mathbf{2}$. This is the first report of compounds $\mathbf{1}-\mathbf{2}$ isolated from U. lobata.

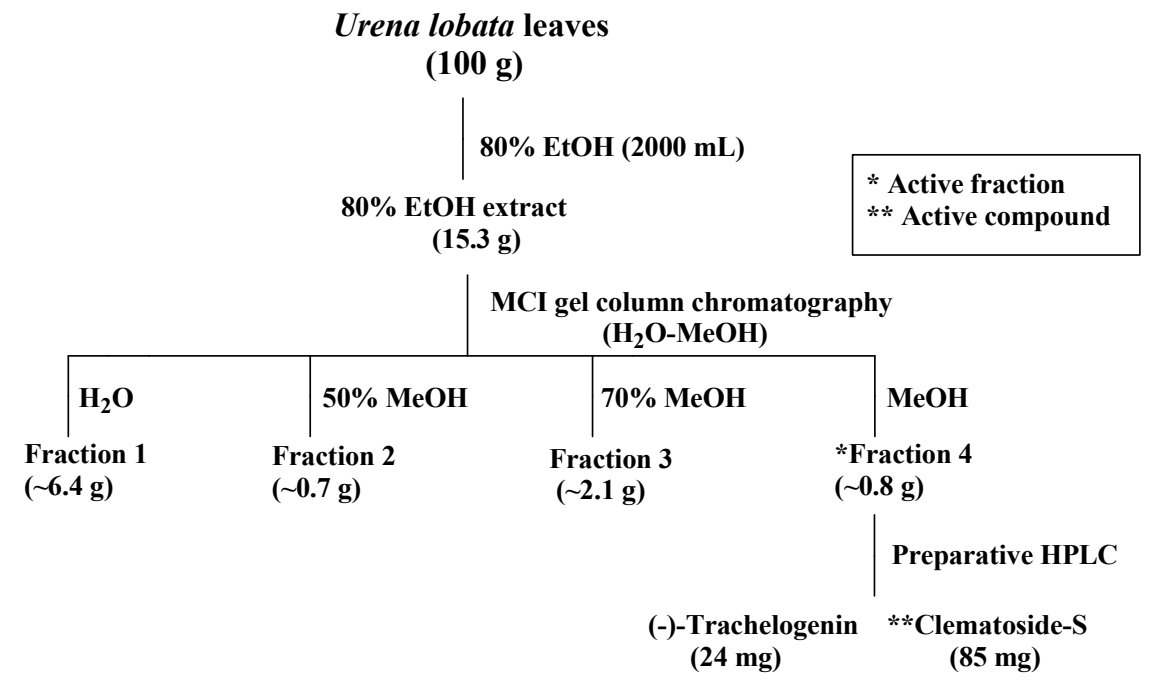

Scheme 1. Isolation scheme of (-)-trachelogenin (1) and clematoside-S (2) from U. lobata.<smiles>COc1cc(C[C@@H]2COC(=O)[C@@]2(O)Cc2ccc(OC)c(OC)c2)ccc1O</smiles>

(-)-Trachelogenin (1)

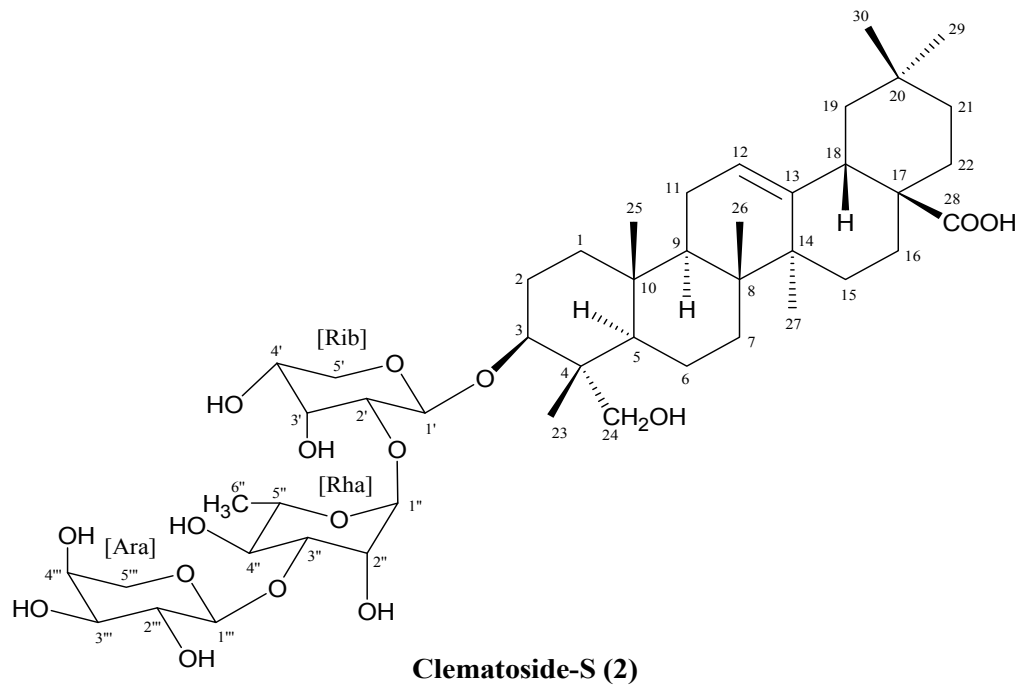

Figure 1. Chemical structure of (-)-trachelogenin (1) and clematoside-S (2). 


\subsection{Identification of Isolated Compounds 1-2}

The chemical structures of the isolated compounds $\mathbf{1}$ and $\mathbf{2}$ were identified by spectroscopic analyses consisting of MS, ${ }^{1} \mathrm{H}-\mathrm{NMR},{ }^{13} \mathrm{C}-\mathrm{NMR}$ and $2 \mathrm{D}-\mathrm{NMR}$ data analyses. By comparison with literature data [14-16], compound 1 was identified as (-)-trachelogenin: pale-yellow gum; electron spray ionization-mass spectrometry (ESI-MS) (negative), $m / z 387.25[\mathrm{M}-\mathrm{H}]^{-}$; electron spray ionization-high resolution mass spectrometry (ESI-HRMS) $\mathrm{m} / z \quad 411.1420$ (calcd. for $\mathrm{C}_{21} \mathrm{H}_{24} \mathrm{O}_{7} \mathrm{Na}, 411.1420$ ); $[\alpha]_{\mathrm{D}}{ }^{25}-32.2^{\circ}\left(c\right.$ 0.43, $\left.\mathrm{CHCI}_{3}\right) ;{ }^{1} \mathrm{H}-\mathrm{NMR} \delta$ (methanol- $\left.d_{4}\right) \mathrm{ppm}(J$ in $\mathrm{Hz}): 2.45(1 \mathrm{H}, \mathrm{m}, \mathrm{H}-8), 2.50(1 \mathrm{H}$, $\left.\mathrm{dd}, J=13.6,4.1, \mathrm{H}_{\mathrm{a}}-7\right), 2.80\left(1 \mathrm{H}, \mathrm{dd}, J=13.6,5.0, \mathrm{H}_{\mathrm{b}}-7\right), 2.85\left(1 \mathrm{H}, \mathrm{d}, J=13.6, \mathrm{H}_{\mathrm{a}-7}\right), 3.12(1 \mathrm{H}, \mathrm{d}$, $\left.J=13.6, \mathrm{Hb}_{\mathrm{b}}-7^{\prime}\right), 3.78$ (3H, s, 3'-OMe), 3.79 (6H, s, 3 and 4-OMe), 3.97 (1H, d, $\left.J=8.8, \mathrm{H}_{\mathrm{a}}-9\right), 3.98$ $\left.(1 \mathrm{H}, \mathrm{d}, J=8.8, \mathrm{Hb}-9), 6.57(1 \mathrm{H}, \mathrm{dd}, J=8.1,1.9, \mathrm{H}-6)^{\prime}\right), 6.70\left(4 \mathrm{H}, \mathrm{m}, \mathrm{H}-2,2^{\prime}, 5^{\prime}\right.$ and 6$), 6.85(1 \mathrm{H}, \mathrm{d}$, $J=8.1, \mathrm{H}-5) .{ }^{13} \mathrm{C}-\mathrm{NMR} \delta(150 \mathrm{MHz}$, methanol-d4) ppm: 30.82 (C-7), 40.50 (C-7'), 43.14 (C-8), 55.04 (3- and 4-OMe), 55.17 (3'-OMe), 70.40 (C-9), 76.01 (C-8'), 111.86 (C-5), 112.53 (C-2), 113.59 (C-2'), 114.69 (C-5'), 120.81 (C-6), 122.68 (C-6'), 126.82 (C-1'), 132.05 (C-1), 145.34 (C-4'), 147.46 (C-3'), 147.76 (C-4), 149.18 (C-3), 179.17 (C-9').

Compound 2 was obtained as white powder. In the FAB-MS spectra (negative mode), deprotonated molecular ion peak of 2 was observed at $m / z 881[\mathrm{M}-\mathrm{H}]^{-}$, while positive fast atom bombardment-mass spectrometry (FAB-MS) showed a highest and base ion peak at $m / z 883[\mathrm{M}+\mathrm{H}]^{+}$. So, these data show that the molecular weight of the active principle is $882 \mathrm{Da}$. The linked-scan spectrum in negative mode showed the fragmentations from the quasi molecular ion of $m / z 881[\mathrm{M}-\mathrm{H}]^{-}$to $\mathrm{m} / \mathrm{z} 750$ $[\mathrm{M}+\mathrm{H}-131]^{-}, 732[\mathrm{M}-\mathrm{H}-149]^{-}, 604[\mathrm{M}-\mathrm{H}-277]^{-}, 585[\mathrm{M}-\mathrm{H}-295]^{-}$, and $471[\mathrm{M}-\mathrm{H}-410]^{-}$, which suggests the active compound is a glycoside containing a sugar moiety of the sequence of pentose-deoxyhexose-pentose. The molecular weight of the aglycone is deduced to be $472 \mathrm{Da}$.

The ${ }^{1}$ H-NMR spectrum apparently showed six tertiary and one secondary methyl signals. The ${ }^{13} \mathrm{C}$-NMR spectrum in $\mathrm{CD}_{3} \mathrm{OD}$ showed 47 signals except for those overlapping with $\mathrm{CD}_{3} \mathrm{OD}$ signals, two of which were assigned to those of acetic acid $\left(\delta_{\mathrm{C}} 29.09 \mathrm{ppm}, \delta_{\mathrm{C}} 175.76 \mathrm{ppm}\right)$. The polarization transfer (DEPT)-135 and DEPT-90 NMR spectra enclosed one methine carbon at $\delta_{\mathrm{C}} 49.17 \mathrm{ppm}$ among the signals overlapping with those of $\mathrm{CD}_{3} \mathrm{OD}$, and showed 7 methyl, 13 methylene, 18 methine, 7 quaternary, and one carbonyl carbon signals to be assigned to the active principle. Since the active principle contains a pentose-deoxyhexose-pentose chain, 30 carbon signals comes from an aglycone, which is expected to be a triterpene. The heteronuclear single quantum coherence (HSQC) spectrum showed the signals of six tertiary and one secondary methyl carbons, the latter of which was assigned to a deoxyhexose by heteronuclear multiple-bond correlation (HMBC) spectrum analysis. The assignments of the protons and carbons are discussed in the following sessions and summarized in Table 1.

The HMQC spectrum showed that a carbinol carbon at $\delta_{\mathrm{C}} 82.28 \mathrm{ppm}$, which was assigned to C-3 of an aglycone, carries a proton at $\delta_{\mathrm{H}} 3.61(\mathrm{H}-3)$, and these showed long range couplings to the anomeric proton and carbon of a sugar, suggesting the linkage between the aglycone and a sugar chain. The proton at $\delta_{\mathrm{H}} 3.61 \mathrm{ppm}(\mathrm{H}-3)$ showed long range couplings to methyl carbon $(\mathrm{C}-23)$ at $\delta_{\mathrm{C}} 13.79 \mathrm{ppm}$ and a quaternary carbon $(\mathrm{C}-4)$ at $\delta_{\mathrm{C}} 43.95 \mathrm{ppm}$. The methyl proton on C-23 long-range coupled to C-4 and a primary carbinyl carbon $(\mathrm{C}-24)$ at $\delta_{\mathrm{C}} 64.58 \mathrm{ppm}$ in addition to the carbinol carbon, $\mathrm{C}-3$, and a methine carbon (C-5) at $\delta_{\mathrm{C}} 48.15 \mathrm{ppm}$. The methine proton at $\delta_{\mathrm{H}} 1.26 \mathrm{ppm}$ on $\mathrm{C}-5$ showed coupling to $\mathrm{C}-6$ at $\delta_{\mathrm{C}} 18.80 \mathrm{ppm}, \mathrm{C}-10$ at $\delta_{\mathrm{C}} 37.61 \mathrm{ppm}$, and C-25 at $\delta_{\mathrm{C}} 16.40 \mathrm{ppm}$ in addition to C-4, C-23, and C-24. 
The methyl proton on $\mathrm{C}-25$ showed a coupling to a methylene carbon at $\delta \mathrm{c} 39.67 \mathrm{ppm}$, which was finally assigned to $\mathrm{C}-1$, in addition to two quaternary carbons at $\delta_{\mathrm{C}} 37.61 \mathrm{ppm}(\mathrm{C}-10)$ and $\delta_{\mathrm{C}} 49.0$ (C-9). The carbinyl proton at $\delta_{\mathrm{H}} 3.61 \mathrm{ppm}(\mathrm{H}-3)$ on $\mathrm{C}-3$ showed vicinal couplings to methylene protons at $\delta \mathrm{H} 1.74 \mathrm{ppm}(\mathrm{H}-2 \mathrm{a}, J=4.5 \mathrm{~Hz})$ and $\delta \mathrm{H} 1.85 \mathrm{ppm}(\mathrm{H}-2 \mathrm{~b}, J=12.2 \mathrm{~Hz})$. These two protons are on the carbon at $\delta_{\mathrm{C}} 26.58 \mathrm{ppm}(\mathrm{C}-2)$, showed a geminal coupling $(J=17.4 \mathrm{~Hz})$, and vicinal couplings to a proton at $\delta_{\mathrm{H}} 1.60 \mathrm{ppm}(\mathrm{H}-1 \mathrm{a})$ on the carbon at $\delta_{\mathrm{C}} 39.67 \mathrm{ppm}(\mathrm{C}-1)$. $\mathrm{H}-1$ shows a geminal coupling to $\mathrm{H}-1 \mathrm{~b}$ at $\delta_{\mathrm{H}} 0.98 \mathrm{ppm}$, which shows vicinal couplings to $\mathrm{H}-2 \mathrm{a}$ and $\mathrm{H}-2 \mathrm{~b}$. Taking all the information mentioned above, a partial structure (ring A) of the aglycone was determined as shown in Figure 1. Of the two olefinic carbon signals at $\delta_{\mathrm{C}} 123.60 \mathrm{ppm}$ and $\delta_{\mathrm{C}} 145.21 \mathrm{ppm}$ which are later assigned to $\mathrm{C}-12$ and $\mathrm{C}-13$, respectively, $\mathrm{C}-12$ carries an olefinic proton at $\delta_{\mathrm{H}} 5.23 \mathrm{ppm}(\mathrm{H}-12)$ which showed long-range couplings to carbons at $\delta_{\mathrm{C}} 24.52 \mathrm{ppm}$ (secondary), $\delta_{\mathrm{C}} 49.0 \mathrm{ppm}(\mathrm{C}-9)$, and $\delta_{\mathrm{C}} 42.72 \mathrm{ppm}$ (tertiary, C-18). The HMQC spectrum showed that the carbon at $\delta_{\mathrm{C}} 24.52 \mathrm{ppm}$ carries protons at $\delta_{\mathrm{H}}$ $1.87 \mathrm{ppm}$ and $\delta_{\mathrm{H}} 1.89 \mathrm{ppm}$, both of which showed couplings to the olefinic proton $(\mathrm{H}-12)$ at $\delta_{\mathrm{H}} 5.23 \mathrm{ppm}$ in the HMBC spectrum. In addition, one or both of the protons appearing at $\delta_{\mathrm{H}} 1.87 \mathrm{ppm}$ and $\delta_{\mathrm{H}} 1.89 \mathrm{ppm}$ showed couplings to both olefinic carbons. These $\mathrm{H}-\mathrm{H}$ and $\mathrm{C}-\mathrm{H}$ couplings suggest that the carbon at $\delta_{\mathrm{C}} 24.52 \mathrm{ppm}$ is vicinal to the carbon at $\delta_{\mathrm{C}} 123.60 \mathrm{ppm}(\mathrm{C}-12)$ to be assigned to $\mathrm{C}-11$. A long rage coupling from the proton at $\delta_{\mathrm{H}} 1.62 \mathrm{ppm}(\mathrm{H}-9)$ on the methine carbon at $\delta_{\mathrm{C}} 49.00 \mathrm{ppm}(\mathrm{C}-9)$ to $\mathrm{C}-11$ was observed. To C-9, were observed long range couplings from $\mathrm{H}-12$ at $\delta_{\mathrm{H}} 5.23 \mathrm{ppm}$ and methyl protons at $\delta_{\mathrm{H}} 0.96 \mathrm{ppm}\left(\mathrm{H}_{3}-25\right)$ and $\delta_{\mathrm{H}} 0.80 \mathrm{ppm}\left(\mathrm{H}_{3}-26\right)$. $\mathrm{H}-9$ couples to $\mathrm{C}-11$ in addition to the carbons at $\delta_{\mathrm{C}} 37.61 \mathrm{ppm}(\mathrm{C}-10), \delta_{\mathrm{C}} 48.15 \mathrm{ppm}(\mathrm{C}-5)$, and $\delta_{\mathrm{C}} 40.50 \mathrm{ppm}(\mathrm{C}-8)$. These couplings enclosed the sequence of C-10/C-9/C-11/C-12/C-13, and the attachment of C-25 on C-10. The methyl protons $\left(\mathrm{H}_{3}-26\right)$ shows a long range coupling to a quaternary carbon at $\delta_{\mathrm{C}} 42.96 \mathrm{ppm}$, which was assigned to C-14, in addition to $\mathrm{C}-9, \mathrm{C}-10$, and the methylene carbon at $\delta_{\mathrm{C}} 33.39 \mathrm{ppm}$ assigned to $\mathrm{C}-8$ through HMQC and $\mathrm{H}^{1}-\mathrm{H}^{1} \mathrm{COSY}$ spectrum analyses. Based on the above information, the partial structure constructing rings $\mathrm{A}, \mathrm{B}$, and $\mathrm{C}$ appeared, and hederagenin came out as the candidate for the aglycone. Comparing our NMR data with those in literatures [17-19], the aglycone was unambiguously identified to be hederagenin.

The linked scan MS suggests the sequence of pentosyl-deoxyhexosyl-pentosyl chain. The D configurations of the arabinose and ribose and the L configuration of rhamnose were established after hydrolysis of 2 followed by GC analysis [20-22]. GC-MS analysis of the trimethylsilylates of $N$-methoximes of the sugars obtained by acid hydrolysis of $\mathbf{2}$ showed the major peaks at $t$ Rs of 15.29 , 15.81 , and $17.18 \mathrm{~min}$, respectively. The $t_{\mathrm{Rs}}$ of these peaks were identical to those of standard silylated samples, showing that the sugar components of the active principle were D-arabinose, D-ribose, and L-rhamnose. The HMBC showed that the carbinyl proton $(\mathrm{H}-3)$ at $\delta \mathrm{H} 3.61 \mathrm{ppm}$ long-range coupled to an anomeric carbon (C-1') at $\delta_{\mathrm{C}} 104.63 \mathrm{ppm}$, and the anomeric proton (1'-H) at $\delta_{\mathrm{H}} 4.51 \mathrm{ppm}$ to $\mathrm{C}-3$ of hederagenin at $\delta_{\mathrm{C}} 82.28 \mathrm{ppm}$. The $J$ value between $\mathrm{H}-1^{\prime}$ and $\mathrm{H}-2^{\prime}\left(\delta_{\mathrm{H}} 3.69 \mathrm{ppm}\right)$ on the carbon $\left(\mathrm{C}-2^{\prime}\right)$ at $\delta_{\mathrm{C}} 76.33 \mathrm{ppm}$ was $6.0 \mathrm{~Hz}$, suggesting the axial-equatorial relation of the two protons, and all signals of the protons and the carbons of the pentose directly attached to hedragenin were assigned as shown in Figure 1 and Table 1. The C-2' and C-3' were distinguished by the long-range coupling from H-5a' and $\mathrm{H}-5 \mathrm{~b}^{\prime}$ to the carbon at $\delta_{\mathrm{C}} 74.21 \mathrm{ppm}\left(\mathrm{C}-3^{\prime}\right)$. Based on the chemical shifts of all signals and the $J$ value $(6.0 \mathrm{~Hz})$ between $\mathrm{H}-1$ ' and $\mathrm{H}-2$ ', the pentose was determined to be $\alpha$-D-ribose (Figure 1). Similarly, all the signals of $\alpha$-L-rhamnose were assigned as shown in Table 1 and the ether linkage from C-2' of 
ribose to $\mathrm{C}-1^{\prime}$ ' of rhamnose was determined by the long-range coupling from $\mathrm{H}-2$ ' of ribose to $\mathrm{C}-1$ " of rhamnose and that from $\mathrm{H}-1$ " of rhamnose to $\mathrm{C}-2$ ' of ribose. The third sugar, arabinose, was determined to be $\beta$-anomer based on the $J$ value $\left(4.3 \mathrm{~Hz}\right.$ ) between $\mathrm{H}-1^{\prime \prime \prime}$ and $\mathrm{H}-2$ "', and all signals of $\beta$-arabinose were assigned as shown Table 1. The long-range coupling from $\mathrm{H}-3$ " to C-1"' and that $\mathrm{H}-1$ "' to C-3" showed the ether linkage between C-3" of rhamnose and C-1"' of arabinose. Finally, the chemical structure

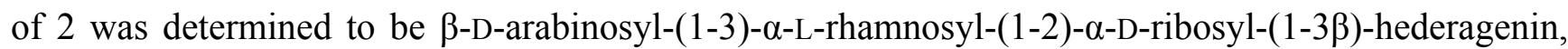
namely clematoside-S.

Table 1. The NMR spectroscopic data for clematoside-S (2) in MeOH- $d 4$.

\begin{tabular}{|c|c|c|c|}
\hline Position & $\boldsymbol{\delta}_{\mathrm{C}}$ & $\delta_{\mathrm{H}}$ (Mult., $J$ in Hz) & HMBC \\
\hline 1 & 39.67 & 0.98 (overlap), $1.60(\mathrm{~m})$ & - \\
\hline 2 & 26.58 & $1.74(\mathrm{~m}), 1.85(\mathrm{~m})$ & - \\
\hline 3 & 82.28 & $3.61(\mathrm{~m})$ & C-4, C-23, C-1' \\
\hline 4 & 43.95 & - & - \\
\hline 5 & 48.15 & $1.26(\mathrm{~m})$ & $\mathrm{C}-4, \mathrm{C}-10, \mathrm{C}-23, \mathrm{C}-25$ \\
\hline 6 & 18.80 & $1.36(\mathrm{~m}), 1.51(\mathrm{~m})$ & - \\
\hline 7 & 33.39 & $1.26(\mathrm{~m}), 1.63(\mathrm{~m})$ & - \\
\hline 8 & 40.50 & - & - \\
\hline 9 & 49.00 & $1.62(\mathrm{~m})$ & C-5, C-8, C-10, C-11 \\
\hline 10 & 37.61 & - & \\
\hline 11 & 24.52 & $1.87(\mathrm{~m}), 1.89(\mathrm{~m})$ & $\mathrm{C}-12, \mathrm{C}-13$ \\
\hline 12 & 123.60 & $5.23(\mathrm{~m})$ & - \\
\hline 13 & 145.21 & - & - \\
\hline 14 & 42.96 & - & - \\
\hline 15 & 28.82 & $1.07(\mathrm{~m}), 1.76(\mathrm{~m})$ & - \\
\hline 16 & 20.05 & $1.61(\mathrm{~m}), 2.01(\mathrm{~m})$ & $\mathrm{C}-28$ \\
\hline 17 & 47.63 & - & - \\
\hline 18 & 42.72 & $2.84(\mathrm{~m})$ & $\mathrm{C}-12, \mathrm{C}-13, \mathrm{C}-17, \mathrm{C}-28$ \\
\hline 19 & 47.22 & $1.12(\mathrm{~m}), 1.69(\mathrm{~m})$ & - \\
\hline 20 & 31.59 & - & - \\
\hline 21 & 34.88 & $1.20(\mathrm{~m}), 1.39(\mathrm{~m})$ & - \\
\hline 22 & 33.81 & $1.53(\mathrm{~m}), 1.74(\mathrm{~m})$ & - \\
\hline 23 & 13.79 & $0.70(\mathrm{~s})$ & C-3, C-4, C-5, C-24 \\
\hline 24 & 43.95 & $3.37(\mathrm{~m}), 3.53(\mathrm{~m})$ & $\mathrm{C}-4, \mathrm{C}-23$ \\
\hline 25 & 16.40 & $0.96(\mathrm{~s})$ & $\mathrm{C}-1, \mathrm{C}-9, \mathrm{C}-10$ \\
\hline 26 & 17.75 & $0.80(\mathrm{~s})$ & C-7, C-8, C-9, C-14 \\
\hline 27 & 26.46 & $1.17(\mathrm{~s})$ & C-13, C-14, C-15 \\
\hline 28 & 181.88 & - & - \\
\hline 29 & 33.57 & $0.90(\mathrm{~s})$ & $\mathrm{C}-19, \mathrm{C}-20, \mathrm{C}-21, \mathrm{C}-30$ \\
\hline 30 & 23.97 & $0.93(\mathrm{~s})$ & C-19, C-20, C-21, C-29 \\
\hline $1^{\prime}$ & 104.63 & $4.51(\mathrm{~d}, J=6.0)$ & $\mathrm{C}-3, \mathrm{C}-5^{\prime}$ \\
\hline $2^{\prime}$ & 76.33 & $3.69(\mathrm{~m})$ & C-1', C-3' \\
\hline $3^{\prime}$ & 74.21 & $3.69(\mathrm{~m})$ & C-1', C-2' \\
\hline $4^{\prime}$ & 69.64 & $3.75(\mathrm{dd}, J=13.8,6.6)$ & - \\
\hline $5^{\prime}$ & 65.44 & $3.5(\mathrm{~d}, J=6.6), 3.83(\mathrm{~d}, J=6.6)$ & $\mathrm{C}-1^{\prime}, \mathrm{C}-3^{\prime}$ \\
\hline
\end{tabular}


Table 1. Cont.

\begin{tabular}{|c|c|c|c|}
\hline Position & $\boldsymbol{\delta}_{\mathrm{C}}$ & $\delta_{\mathrm{H}}$ (Mult., $J$ in Hz) & НMBC \\
\hline $1 "$ & 101.52 & $5.21(\mathrm{~d}, J=1.6)$ & C-2', C-2", C-3", C-5" \\
\hline $2^{\prime \prime}$ & 71.73 & $4.05(\mathrm{~d}, J=2.4)$ & C-3", C-4" \\
\hline $3 "$ & 80.70 & $3.83(\mathrm{~d}, J=13.8)$ & C-4", C-1"' \\
\hline $4 "$ & 72.96 & $3.83(\mathrm{~d}, J=13.8)$ & C-3", C-5" \\
\hline $5 "$ & 70.33 & $3.90(\mathrm{~d}, J=7.2)$ & - \\
\hline $6 "$ & 17.99 & $1.23(\mathrm{~m})$ & C-5" \\
\hline $1 " '$ & 104.18 & $4.99(\mathrm{~d}, J=4.3)$ & C-3", C-3"' \\
\hline $2^{\prime \prime \prime}$ & 72.60 & $3.67(\mathrm{~d}, J=3.2)$ & C-1"', C-3"' \\
\hline $3^{\prime \prime \prime}$ & 68.66 & $3.96(\mathrm{~d}, J=3.2)$ & C-1"' \\
\hline $4^{\prime \prime \prime}$ & 70.17 & $3.76(\mathrm{dd}, J=13.2,6.6)$ & C-1"', C-4"' \\
\hline $5^{\prime \prime \prime}$ & 65.13 & $3.67(\mathrm{~d}, J=13.2), 3.89(\mathrm{~d}, J=13.2)$ & - \\
\hline
\end{tabular}

\subsection{Antimicrobial Activity of Isolated Active Compound}

The antimicrobial activity of the $80 \%$ ethanol extract from $U$. lobata leaves was evaluated using Oxford plate method against five strains of food-borne bacteria (Eschericha coli, Salmonella typhimurium, Staphylpcocuus aureus, Bacillus subtilis, and Bacillus laterosporus), four strains of fungi (Aspergillus flavus, Aspergillus niger, Rhizopus oryzae, and Pencicillum citrinum), and six yeast strains (Candida albicans, Saccharomyces cerevisiae ATCC 204505, Saccharomyces cerevisiael AY529515.1, Saccharomyces cerevisiae $\backslash A J 746340.1$, Saccharomyces cerevisiae $\backslash J X 103178.1$, and Saccharomyces boulardii KG254081.1) as shown in Table 2. The solvent (95\% methanol) used as the negative control did not show any activity. At a concentration of $10 \mathrm{mg} / \mathrm{mL}$, the crude extract showed no antibacterial activity. Meanwhile, the extract was inactive against three species of fungi (A. flavus, R. oryzae, and $P$. citrinum) even at $10 \mathrm{mg} / \mathrm{mL}$. Among the test fungi, the most sensitive strain was A. niger with the diameter of inhibition zone of $9 \mathrm{~mm}$. The extract showed no activity $(10 \mathrm{mg} / \mathrm{mL})$ against $C$. albicans. It was worth noting that the extract exhibited remarkable anti-yeast activities against $S$. cerevisiae ATCC 204505, S. cerevisiae $\backslash$ AY529515.1, S. cerevisiae $\backslash A J 746340.1$, S. cerevisiae $J X 103178.1$, and $S$. boulardii $\backslash \mathrm{KG} 254081.1$ with the diameter of the inhibition zone in the range from 14 to $17 \mathrm{~mm}$. The result suggest that $U$. lobata leaves inhibits selectively the growth of some yeast strains. So, we selected out S. cerevisiae ATCC 204505 as the indicator for detecting the main anti-yeast substance(s) in U. lobata leaves. Using a combination of chromatographic methods, (-)-trachelogenin (1) and clematoside-S (2) were isolated from the $80 \%$ ethanol extract of $U$. lobata leaves. It was found that $\mathbf{1}$ showed no activity against all of the selected microorganisms in the antimicrobial assay (Table 2). However, $\mathbf{2}$ showed promising activity against $S$. cerevisiae ATCC 204505 as compared to standard anti-yeast reagent, streptomycin. In addition, $\mathbf{2}$ exhibited a potent inhibitory effect against the five test yeast strains, except for $C$. albicans, with diameter of inhibition zones in the range from 11 to $20 \mathrm{~mm}$.

Further study was carried out to investigate the anti-yeast effect of $\mathbf{2}$ against $S$. cerevisiae ATCC 204505, S. cerevisiae $\backslash$ AY529515.1, S. cerevisiae $\backslash A J 746340.1$, S. cerevisiae $\backslash J X 103178.1$, and S. boulardii $\backslash \mathrm{KG} 254081.1$ by measuring the minimum inhibitory concentration (MIC) and the minimum bactericidal concentration (MBC). The MICs and MBCs of 2 to the five test yeast strains 
were shown in Table 3. These results demonstrated that $\mathbf{2}$ had certain antibacterial and bactericidal property. In general, the MICs of 2 against the test yeasts were in range from 0.61 to $9.80 \mu \mathrm{g} / \mathrm{mL}$, and MBCs from 2.42 to $9.80 \mu \mathrm{g} / \mathrm{mL}$, respectively. Associated with the results of disc diameter of inhibition zone in Table 2, it was clearly indicated that $\mathbf{2}$ showed the strongest activity against $S$. cerevisiae ATCC 204505, whereas it showed the moderate activity against the other yeast strains (Table 3). clematoside-S (2) isolated from clematotic species has been reported to exhibit cytotoxic activity against several cancer cells [23]. However, compound $\mathbf{2}$ has never been studied for antimicrobial activity. Our finding is the first report on the isolation of $\mathbf{2}$ with anti-yeast activity from U. lobata. Therefore, it may be proposed that $U$. lobata can be used as a natural anti-yeast agent to control food spoilage caused by yeast. However, further study is warranted to provide clear evidence for toxicity profile.

Table 2. Antimicrobial activity of $U$. lobata extract, Fra. 4, (-)-trachelogenin (1) and clematoside-S (2).

\begin{tabular}{|c|c|c|c|c|c|c|}
\hline \multirow{2}{*}{ Microorganisms Strain } & \multicolumn{6}{|c|}{ Inhibition Zone (mm) } \\
\hline & Extract a & Fra. $4^{\text {b }}$ & $1^{\mathrm{c}}$ & $2^{\mathrm{c}}$ & Negative Control $^{\mathrm{d}}$ & Positive Control $^{\mathrm{e}}$ \\
\hline \multicolumn{7}{|l|}{ Gram negative bacteria } \\
\hline Eschericha coli ATCC 25922 & 0 & $N T^{f}$ & 0 & 0 & 0 & 35 \\
\hline Salmonella typhimurium ATCC 14028 & 0 & NT & 0 & 0 & 0 & 28 \\
\hline \multicolumn{7}{|l|}{ Gram positive bacteria } \\
\hline Staphylpcocuus aureus ATCC 25923 & 0 & NT & 0 & 0 & 0 & 28 \\
\hline Bacillus subtilis ATCC 21216 & 0 & NT & 0 & 0 & 0 & 18 \\
\hline Bacillus cereus ATCC 10231 & 0 & NT & 0 & 0 & 0 & 15 \\
\hline Bacillus laterosporus ATCC 64 & 0 & NT & 0 & 0 & 0 & 21 \\
\hline \multicolumn{7}{|l|}{ Fungi } \\
\hline Aspergillus flavus ATCC 204304 & 0 & NT & 0 & 0 & 0 & 25 \\
\hline Aspergillus niger ATCC 16404 & 9 & NT & 0 & 9 & 0 & 20 \\
\hline Rhizopus oryzae ATCC 9363 & 0 & NT & 0 & 0 & 0 & 28 \\
\hline Pencicillum citrinum ATCC 14994 & 0 & NT & 0 & 0 & 0 & 26 \\
\hline \multicolumn{7}{|l|}{ Yeasts $\mathrm{g}$} \\
\hline Candida albicans ATCC 50013 & 0 & NT & 0 & 0 & 0 & 0 \\
\hline Saccharomyces cerevisiae ATCC 204508 & 15 & 16 & 0 & 20 & 0 & 21 \\
\hline Saccharomyces cerevisiae AY529515.1 & 17 & NT & 0 & 11 & 0 & 21 \\
\hline Saccharomyces cerevisiae AJ746340.1 & 14 & NT & 0 & 12 & 0 & 21 \\
\hline Saccharomyces cerevisiae JX103178.1 & 14 & NT & 0 & 12 & 0 & 21 \\
\hline Saccharomyces boulardii KG254081.1 & 17 & NT & 0 & 13 & 0 & 21 \\
\hline
\end{tabular}

a The concentration of the $80 \%$ ethanol extract from $U$. lobata leaves was $2 \mathrm{mg} / \mathrm{disk}$; ${ }^{\mathrm{b}}$ Fra. 4 (fraction 4) was obtained due to Scheme 1; ${ }^{c}$ The concentration of compounds 1-2 was $2 \mathrm{mg} / \mathrm{disk}$; ${ }^{\mathrm{d}}$ 95\% methanol as the negative control; ${ }^{\text {e }}$ Penicillin ( $2 \mathrm{mg} /$ disk) as the positive control against bacteria and streptomycin ( $\left.2 \mathrm{mg} / \mathrm{disk}\right)$ as the positive control against fungi and yeasts; f Not tested; g Saccharomyces cerevisiae \AY529515.1, Saccharomyces cerevisiae \AJ746340.1, Saccharomyces cerevisiae \X103178.1, and Saccharomyces boulardii KG254081.1 were isolated from spoiled grapes. 
Table 3. MIC ${ }^{\mathrm{a}}$ and $\mathrm{MBC}^{\mathrm{b}}$ of clematoside-S (2) for different yeast strains.

\begin{tabular}{ccc}
\hline Yest Strains & MIC $(\boldsymbol{\mu} \mathbf{g} / \mathbf{m L})$ & MBC $(\boldsymbol{\mu g} / \mathbf{m L})$ \\
\hline Saccharomyces cerevisiae ATCC 204505 & 0.61 & 2.42 \\
Saccharomyces cerevisiae $\backslash$ AY529515.1 & 1.21 & 4.84 \\
Saccharomyces cerevisiae $\backslash A J 746340.1$ & 9.80 & 9.80 \\
Saccharomyces cerevisiae $\backslash J X 103178.1$ & 1.21 & 4.84 \\
Saccharomyces boulardii $\backslash \mathrm{KG} 254081.1$ & 2.42 & 9.80 \\
\hline
\end{tabular}

${ }^{\mathrm{a}}$ Minimum inhibitory concentration (MIC); ${ }^{b}$ Minimum bactericidal concentration (MBC).

\section{Experimental}

\subsection{General Procedure}

ESIMS spectra were acquired on a Thermo Finnigan TSQ Quantum Ultra AM mass spectrometer system with an electrospray source operating in both positive and negative ion modes (Thermo Electron, San Jose, CA, USA). Fast atom bombardment (FAB) MS was obtained with a Jeol JMS-SX102A instrument (JEOL, Tokyo, Japan). Optical rotation values were measured on JASCO P-1020 polarimeter (JASCO, Tokyo, Japan). NMR spectra were recorded with a Bruker AV II-600 instrument $\left({ }^{1} \mathrm{H}, 600 \mathrm{MHz}\right.$; ${ }^{13} \mathrm{C}, 125 \mathrm{MHz}$ ) (Bruker Co., Karlsruhe, Germany). Column chromatography was performed with MCI gel 100A (75-150 $\mu \mathrm{m}$, Sci-Bio-Chem Co., Ltd., Chengdu, China). The HPLC system (Agilent 1200 Series Purification System, Aglilent, Santa Clara, CA, USA) consisted of an injector (G1328B), a column oven $\left(35^{\circ} \mathrm{C}\right)$, a pump (G1311A), a diode array detector (G1315D), and an Inertsil PREP-ODS column $(6 \times 250 \mathrm{~mm}$ i.d. with a particle size of $5 \mu \mathrm{m}$, GL-Science, Tokyo, Japan). The solvents used were all of HPLC-grade for HPLC analysis.

\subsection{Plant Material and Regents}

The leaves of $U$. lobata used in this study were purchased from Chengdu Medicinal Materials (Chengdu, China) and properly identified at the Department of Pharmacology, Hua Xi Medicinal Center of Sichuan University, China. A voucher specimen is deposited in the Rice Research Institute, Sichuan Agricultural University (No. 20090603). Penicillin and streptomycin were obtained from Sichuan Changwei Pharmaceutical Co., Ltd. (Chengdu, China). Agar, beef extract, sucrose and peptone were purchased from Chengdu Best Reagents Co., Ltd. (Chengdu, China). All other reagents used were of analytical grade.

\subsection{Extraction and Isolation of the Active Compound}

The dried leaves of $U$. lobata (100 g) was crushed into powders with a mixer, followed by extraction with $80 \%$ ethanol $(2000 \mathrm{~mL})$ in total for 3 day at room temperature and filtered. Evaporation of the solvent under reduced pressure yielded the $80 \%$ ethanol extract $(15.3 \mathrm{~g})$, which was applied on a MCI gel column $(3.5 \times 20 \mathrm{~cm})$ with a water-methanol gradient to give four fractions (fraction 1, water $(800 \mathrm{~mL}, \sim 6.4 \mathrm{~g})$; fraction $2,50 \%$ methanol in water $(800 \mathrm{~mL}, 0.7 \mathrm{~g})$; fraction $3,70 \%$ methanol in water $(800 \mathrm{~mL}, 2.1 \mathrm{~g})$; fraction $4,100 \%$ methanol $(600 \mathrm{~mL}, 0.8 \mathrm{~g}))$. Consequently, fraction 4 was further purified by preparative HPLC (column, Inertsil ODS $6 \times 250 \mathrm{~mm}$ i.d. with a particle size of 
$5 \mu \mathrm{m}$, GL-Science; mobile phase, water-methanol = 20:80; flow rate, $1 \mathrm{~mL} / \mathrm{min}$; detection, UV $220 \mathrm{~nm}$ ) to yield $24 \mathrm{mg}$ of (-)-trachelogenin $\left(\mathbf{1}, t_{\mathrm{R}} 12.8 \mathrm{~min}\right)$ and $85 \mathrm{mg}$ of clematoside $\mathrm{S}\left(2, t_{\mathrm{R}} 15.4 \mathrm{~min}\right)$.

\subsection{Acid Hydrolysis and GC-MS of Sugars}

A part $(2.1 \mathrm{mg})$ of 2 was dissolved in $2 \mathrm{M} \mathrm{HCl}(5 \% \mathrm{MeOH}, 1 \mathrm{~mL})$ and heated at $95{ }^{\circ} \mathrm{C}$ for $90 \mathrm{~min}$. After the hydrolysis, EtOAc $(2 \mathrm{~mL})$ was added to the solution and voltexed to remove aglycone. This extraction was repeated twice. The aqueous residue was divided into two microtubes, and subjected to a centrifuge-concentration in vacuo. The dried concentrate was converted to $N$-methoximes in $50 \mu \mathrm{L}$ of pyridine containing methoxyamine hydrochloride $(15 \mathrm{mg} / \mathrm{mL})$ overnight at room temperature. To this reaction mixture, $30 \mathrm{~mL}$ of MSTFA ( $N$-methyl- $N$-trimethylsilyltrifuloroacetamide) was added and heated at $45{ }^{\circ} \mathrm{C}$ for $20 \mathrm{~min}$ for trimethylsilylation. The trimethylsilylated $N$-methoxime sugars were submitted to GC-MS analysis under the following condition: column, DB-1 $(0.25 \mathrm{~mm}$ i.d. $\times 25 \mathrm{~m}, 0.25 \mu \mathrm{m})$; injector temperature, $250{ }^{\circ} \mathrm{C}$; carrier gas, $\mathrm{He}(0.9 \mathrm{~mL} / \mathrm{min})$; oven temperature program, $70{ }^{\circ} \mathrm{C}(1 \mathrm{~min})$, $70-150{ }^{\circ} \mathrm{C}\left(20{ }^{\circ} \mathrm{C} / \mathrm{min}\right), 150-180{ }^{\circ} \mathrm{C}\left(2{ }^{\circ} \mathrm{C} / \mathrm{min}\right)$; ionization, EI $(70 \mathrm{eV})$.

\subsection{Antimicrobial Activity}

The tested microorganisms contained Gram-negative bacteria (Escherichia coli ATCC 25922, Salmonella typhimurium ATCC 14028), Gram-positive bacteria (Staphylpcoccus aureus ATCC 25923, Bacillus subtilis ATCC 21216, Bacillus cereus ATCC 10231, Bacillus laterosporus ATCC 64), fungi (Aspergillus niger ATCC 16404, Aspergillus flavus ATCC 204304, Pencicillium citrinum ATCC 14994, and Rhizopus oryzae ATCC 9363) and yeasts (Candida albicans ATCC 50013, Saccharomyces cerevisiae ATCC 204508, Saccharomyces cerevisiae $\backslash A Y 529515.1$, Saccharomyces cerevisiae $\backslash A J 746340.1$, Saccharomyces cerevisiae $\backslash J X 103178.1$, and Saccharomyces boulardii $\backslash$ KG254081.1), and were obtained from the Key Laboratory of Food Science and Technology of Sichuan Province, Sichuan University. The yeasts (Saccharomyces cerevisiae $\backslash A Y 529515.1$, Saccharomyces cerevisiae $\backslash A J 746340.1$, Saccharomyces cerevisiae $\backslash X 103178.1$, and Saccharomyces boulardii $\backslash$ KG254081.1) were isolated from spoiled grapes and identified by morphology, biochemical tests and ITS sequence analysis. All the microorganisms were maintained on nutrient agar at $4{ }^{\circ} \mathrm{C}$ and were sub-cultured every month in our laboratory. In the present test, nutrient agar culture medium was for bacteria and the medium of potatoes was for fungi and yeasts strains.

Antimicrobial activity of the test sample was determined by Oxford plate method [24]. In short, bacterial cultures were diluted to obtain a bacterial suspension of $10^{6} \mathrm{CFU} / \mathrm{mL}$ with sterile water. Petri plates containing $20 \mathrm{~mL}$ of nutrient agar were inoculated with $0.2 \mathrm{~mL}$ of bacterial culture and were allowed to dry in sterile chamber. The Oxford plates $(6 \mathrm{~mm}$ in diameter) were impregnated with $0.1 \mathrm{~mL}$ of test sample in $95 \%$ methanol and placed on the inoculated agar. Penicillin and streptomycin were used as the positive control for bacteria and fungus, respectively. The inoculated plates of bacteria were incubated at $37{ }^{\circ} \mathrm{C}$ for $24 \mathrm{~h}$, and fungi were incubated at $35-37{ }^{\circ} \mathrm{C}$ for $48 \mathrm{~h}$. The antimicrobial activity was evaluated by measuring the zone of inhibition against the test organisms.

The minimum inhibitory concentration (MIC) of the test sample was evaluated for the yeast strains which were determined by the method of broth dilution [25]. An aliquot of $2 \mathrm{~mL}$ of the medium of potatoes was placed into each tube, and all tubes were autoclaved at $121{ }^{\circ} \mathrm{C}$. Test sample (filtered, 
$0.22 \mu \mathrm{m})$ was added to the tubes to keep the final concentrations ranging from 0.06 to $40 \mu \mathrm{g} / \mathrm{mL}$. The test yeast suspension was added into to the inoculum size of $10^{6} \mathrm{CFU} / \mathrm{mL}$. Then, the inoculated tubes were incubated at $37{ }^{\circ} \mathrm{C}$ for $18-24 \mathrm{~h}$. The MIC was evaluated by measuring the turbidity of inoculated culture media. Another liquid medium without adding any yeast was prepared as the negative control. The minimum inhibitory concentration at which no microorganism grew in the culture media was defined as the value of MIC. The minimum bactericidal concentration (MBC) of the test sample was determined according to the MIC values. The sample showing no increases in turbidity were streaked on potatoes medium and incubated at $37^{\circ} \mathrm{C}$ for $18-24 \mathrm{~h}$. The lowest concentration of the test sample where was no viable yeasts was identified as the value of MBC.

\section{Conclusions}

In the present study, (-)-trachelogenin (1) and clematoside-S (2) were isolated from the leaves of $U$. lobata for the first time by a combination of chromatographic methods and their chemical structure was identified by MS and extensive NMR data analysis. Furthermore, to the best of our knowledge, this is the first study demonstrating the antimicrobial activity of clematoside-S. In addition, clematoside-S shows a specific anti-yeast activity against $S$. cerevisiae strains, which are one of the most significant spoilage yeasts for juice and soft drinks.

\section{Acknowledgments}

We are grateful to Peng-Chi Deng, Analytical \& Testing Center, Sichuan University, for his skillful NMR spectral measurements. We are grateful to Isomaro Yamaguchi, Graduate School of Agricultural and Life Sciences/Faculty of Agriculture, The University of Tokyo, for his helpful comments and suggestions. This work was supported by funds of the program for new century excellent talents in university (NCET-10-0591) and Sichuan Youth Sci-tech Fund (2012JQ0019).

\section{Author Contributions}

Xiao-Ling Gao, Ying Liao, Jie Wang, and Xiao-Yan Liu performed the experiments. Kai Zhong, Yi-Na Huang, and Hong Gao analyzed the data. Bo Gao and Zheng-Jun Xu designed the experiments.

\section{Conflicts of Interest}

The authors declare no conflict of interest.

\section{References}

1. Goretti, M.; Turchetti, B.; Buratta, M.; Branda, E.; Cxorazzi, L.; Vaughan-Martini, A.; Buzzini, P. In vitro antimycotic activity of a Williopsis saturnus killer protein against food spoilage yeasts. Int. J. Food Microbiol. 2009, 131, 178-182.

2. Belletti, N.; Kamdem, S.S.; Patrignani, F.; Lanciotti, R.; Covelli, A.; Gardini, F. Antimicrobial activity of aroma compounds against Saccharomyces cerevisiae and improvement of microbiological stability of soft drinks as assessed by logistic regression. Appl. Environ. Microbiol. 2007, 73, 5580-5586. 
3. Loureiro, V.; Querol, A. The prevalence and control of spoilage yeasts in foods and beverages. Trends Food Sci. Technol. 1999, 10, 156-165.

4. Tserennadmid, R.; Takó, M.; Galgóczy, L.; Papp, T.; Pesti, M.; Vágvölgyi, C.; Almássy, K.; Krisch, J. Anti yeast activities of some essential oils in growth medium, fruit juices and milk. Int. J. Food Microbiol. 2011, 144, 480-486.

5. Burt, S. Essential oils: Their antibacterial properties and potential applications in foods-A review. Int. J. Food Microbiol. 2004, 94, 223-253.

6. Tyagi, A.K.; Gottardi, D.; Malik, A.; Guerzoni, M.E. Anti-yeast activity of mentha oil and vapours through in vitro and in vivo (real fruit juices) assays. Food Chem. 2013, 137, 108-114.

7. De las Heras, B.; Slowing, K.; Benedí, J.; Carretero, E.; Ortega, T.; Toledo, C.; Bermejo, P.; Iglesias, I.; Abad, M.J.; Gómez-Serranillos, P.; et al. Antiinflammatory and antioxidant activity of plants used in traditional medicine in Ecuador. J. Ethnopharmacol. 1998, 61, 161-166.

8. Pieme, C.A.; Penlap, V.N.; Ngogang, J.; Costache, M. In vitro cytotoxicity and antioxidant activities of five medicinal plants of Malvaceae family from Cameroon. Environ. Toxicol. Pharmacol. 2010, 29, 223-228.

9. Mazumder, U.K.; Gupta, M.; Manikandan, L.; Bhattacharya, S. Antibacterial activity of Urena lobata root. Fitoterapia 2001, 72, 927-929.

10. Meléndez, P.A.; Capriles, V.A. Antibacterial properties of tropical plants from Puerto Rico. Phytomedicine 2006, 13, 272-276.

11. Xie, Z.; Zeng, H.S.; Liu, C.; Chen, Y.; Zhong, M.Y. Simultaneous quantification of protocatechuic acid, caffeic acid, quercetin and kaempferol in Urena lobata L. by HPLC-VWD. Lat. Am. J. Pharm. 2013, 32, 272-276.

12. Morelli, G.F.; Cairoli, P.; Speranza, G.; Alamgir, M.; Rajia, S. Triglycerides from Urena lobata. Fitoterapia 2006, 77, 296-299.

13. Jia, L.; Bi, Y.F.; Jing, L.L.; Zhou, S.A.; Kong, D.Y. Two new compounds from Urena lobata L. J. Asian Nat. Prod. Res. 2010, 12, 962-967.

14. John, L.M.D.; Tinto, W.F. Revised ${ }^{13}$ C-NMR assignments for the biologically active butyrolactone (-)-trachelogenin. J. Nat. Prod. 1992, 55, 1313-1314.

15. Lima, O.O.A.; Braz-Filho, R. Dibenzylbutyrolactone lignans and coumarins from Ipomoea cairica. J. Braz. Chem. Soc. 1997, 8, 235-238.

16. Boldizsár, I.; Kraszni, M.; Tóth, F.; Noszál, B.; Molnár-Perl, I. Complementary fragmentation pattern analysis by gas chromatography-mass spectrometry and liquid chromatography tandem mass spectrometry confirmed the precious lignan content of Cirsium weeds. J. Chromatogr. A 2010, 1133, 6281-6289.

17. Yokosuka, A.; Sano, T.; Hashimoto, K.; Sakagami, H.; Mimaki, Y. Triterpene glycosides from the whole plant of Anemone hupehensis var. japonica and their cytotoxic activity. Chem. Pharm. Bull. 2009, 57, 1425-1430.

18. Mizutani, K.; Ohtani, K.; Wei, J.X.; Tanaka, O. Saponins from Anemone rivularis. Planta Med. 1984, 50, 327-331.

19. Sati, O.P.; Uniyal, S.K.; Bahuguna, S.; Kikuchi, T. Clematoside-S, a triterpenoid saponin from the roots of Clematis grata. Phytochemistry 1990, 29, 3676-3678. 
20. Hara, S.; Okabe, H.; Mihashi, K. Gas-liquid chromatographic separation of aldose enantiomers as trimethylsilyl ethers of methyl 2-(polyhydroxyakyl)-thiazolidine-4-(R)-carboxylates. Chem. Pharm. Bull. 1987, 35, 501-506.

21. Mitaine-Offer, A.C.; Pénez, N.; Miyamoto, T.; Delaude, C.; Mirjolet, J.F.; Duchamp, O.; Lacaille-Dubois, M.A. Acylated triterpene saponins from the roots of Securidaca longepedunculata. Phytochemistry 2010, 71, 90-94.

22. Pawelec, S.; Jedrejek, D.; Kowalczyk, M.; Pecio, L.; Masullo, M.; Piacente, S.; Macias, F.A.; Simonet, A.M.; Oleszek, W.; Stochmal, A. Triterpene saponins from the aerial parts of Trifolium medium L. var. sarosiense. J. Agric. Food Chem. 2013, 61, 9789-9796.

23. Yan, L.H.; Xu, L.Z.; Lin, L.; Yang, S.L.; Feng, Y.L. Triterpenoid saponins from the stems of Clematis parviloba. J. Asian Nat. Prod. Res. 2009, 11, 332-338.

24. Zeng, W.C.; Jia, L.R.; Zhang, Y.; Cen, J.Q.; Chen, X.; Gao, H.; Huang, Y.N. Antibrowning and antimicrobial activities of the water-soluble extract from pine needles of Cedrus deodara. J. Food Sci. 2011, 76, 318-323.

25. Zeng, W.C.; Zhu, R.X.; Jia, L.R.; Gao, H.; Zheng, Y.; Sun, Q. Chemical composition, antimicrobial and antioxidant activities of essential oil from Gnaphlium affine. Food Chem. Toxicol. 2011, 49, $1322-1328$.

(C) 2015 by the authors; licensee MDPI, Basel, Switzerland. This article is an open access article distributed under the terms and conditions of the Creative Commons Attribution license (http://creativecommons.org/licenses/by/4.0/). 